\title{
Бирюкова Н.В., Ханова П.В. \\ Обзор методов борьбы с инвазивными видами животных в применении к остановке инвазии испанского слизня вида Arion vulgaris
}

ФГАОУ ВО Первый МГМУ имени И.М. Сеченова Минздрава России (Сеченовский Университет)

(Россия, Москва)

doi: $10.18411 / \mathrm{j}-06-2021-30$

\section{Аннотация}

В статье представлен обзор самых неординарных и в то же время действенных методов борьбы с различными инвазивными видами животных, а также перечислены факторы, без учёта которых прекращение инвазии было бы невозможно. Подобные методы могут служить примером действий при разработке стратегии борьбы с Испанским слизнем, который входит с список наиболее опасных инвазионных видов России.

Ключевые слова: инвазивный вид, Испанский слизень, Arion vulgaris.

\section{Abstract}

The article provides an overview of the most extraordinary and at the same time effective methods of dealing with various invasive animal species, as well as lists the factors without taking into account which the termination of the invasion would be impossible. Such methods can serve as an example of actions when developing a strategy to combat the Spanish slug, which is included in the list of the most dangerous invasive species in Russia.

Keywords: invasive species, Spanish slug, Arion vulgaris.

\section{Введение}

В современном мире стремительно развиваются торговые связи, а интенсивность различных перевозок между странами и разными территориями внутри стран способствует тому, что некоторые виды животных и растений попадают туда, где их раньше не было, и некоторые из них становятся инвазивными видами. Эти виды, если на новых территориях у них нет естественных врагов, начинают стремительно размножаться, осваивая новые пространства, вытесняя с них виды-аборигены, что иногда приводит к исчезновению целых экосистем. На территории России продолжается активное распространение опасного инвазивного вида - испанского придорожного слизня.

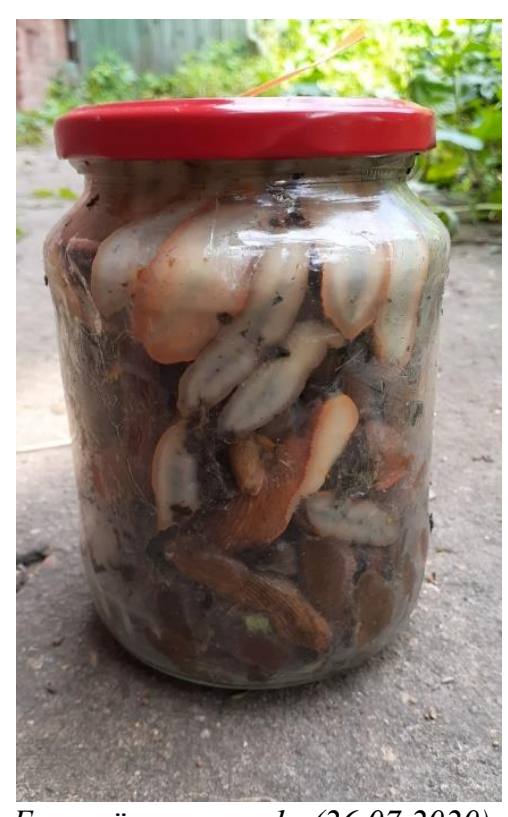

Банка ёмкостью 1л (26.07.2020)

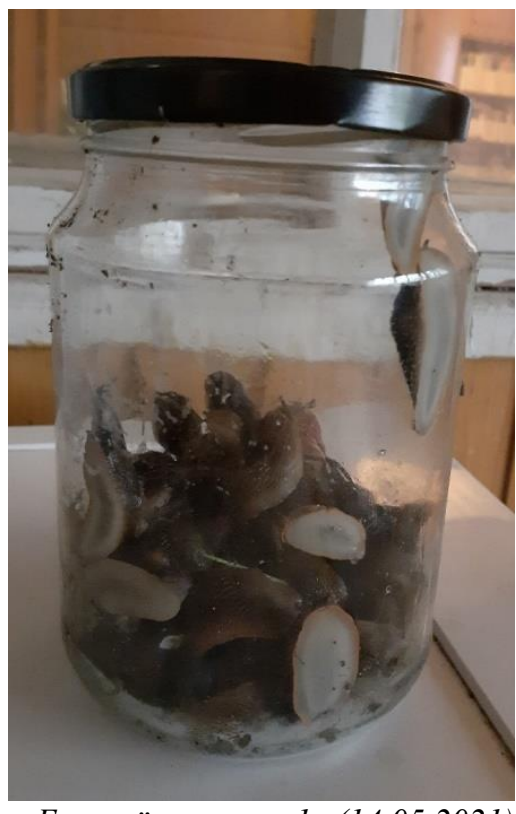

Банка ёмкостью 1л (14.05.2021) 
Испанский слизень находится в списке наиболее опасных инвазивных видов России, включающем 100 видов. Список создан и обновляется Бельгийским Институтом исследований природы и леса (Research Institute for Nature and Forest) и Британским центром экологии и гидрологии (Centre for Ecology and Hydrology). По данным вышеперечисленных организаций, испанский слизень - один из худших вредителей, отрицательно влияющих на экономику, экологию и здравоохранение стран Европы. [1]

Есть предположение, что испанский слизень распространился в России вместе с поставками овощей и фруктов, посадочного материала, приспособился к условиям окружающей среды, способен переживать засуху и сильные морозы. Обычно местных слизней поедают ежи, разные виды птиц, а также рептилии, жужелицы и некоторые виды светляков. Что касается испанского слизня, то его естественных врагов в нашей природе не найдено, что позволяет виду беспрепятственно размножаться.

Моллюск практически всеяден: он питается растениями, падалью, дождевыми червями. При высокой численности популяции испанский слизень поедает даже себе подобных. По данным польских зоологов, слизень добирается до гнёзд птиц, гнездящихся на земле и в невысоком кустарнике, и наносит смертельный вред птенцам [2].

Нашествие испанского слизня также опасно и для человека. Слизень является переносчиком множества инфекций, в числе которых кишечная палочка, а также гельминтов (бычий и крысиный цепни) и нематод (Angiostrongylus cantonensis, способной вызывать менингит). Большую опасность слизень представляет и для животноводства, так как скот, поедая на выпасе растения, испачканные слизью, или зараженный силос, может заразиться ботулизмом - острым инфекционным заболеванием, в результате которого возникают необратимые поражения нервной системы, сопровождающееся высокой летальностью (около 90-95 \%).

\section{Методы борьбы с распространением испанского слизня}

Борьба с испанский слизнем уже давно ведется в Европе, например, на Украине была создана UkrBIN - сеть, пользоваться которой могут не только специалисты, но и просто заинтересованные в определении вида граждане. Статистическая информация сети позволяет оценить реальную картину присутствия или отсутствия того или иного вида животных и растений. Люди рассказывают о проблемах, которые он создает. Слизень всеяден - цветы и растения, преимущественно овощи, может за несколько часов съесть кабачок, который больше него раз в десять, залезает в подвалы и поедает запасы овощей. Установлено, что на время развития яйца и вылупления моллюсков значительно влияют температура и влажность. Зная, при каких условиях распространяется этот вид моллюсков, можно с высокой вероятностью прогнозировать районы его успешной интродукции. Чтобы убедиться в масштабах проблемы достаточно зайти в группу, где ученые на волонтерских началах собирают информацию о распространении рыжего испанского слизня.

Появилась некоторая напряженность и в России, но осведомлённость населения о потенциальной опасности в нашей стране крайне мала. Тем временем, ситуация в Эстонии и Финляндии близка к критической. Власти установили на улицах контейнеры для сбора и утилизации слизней. В Эстонии существует специальное мобильное приложение для регистрации на карте мест, в которых обнаружены слизни - чтобы эстонский Департамент окружающей среды отслеживал рост популяции вредителя и предпринимал необходимые меры. Для информирования своего населения Латвийское 
управление природоохраны в 2019 году выпустило мультфильм о нашествии слизней [3].

В открытых источниках интернета можно найти множество способов борьбы с испанским слизнем, но на практике все способы малоэффективны. Наиболее известное средство среди гербицидов, содержащее фосфат железа, рекламируется как действенное и безопасное, однако оно способно уничтожить не только испанских слизней, но и другие безвредные виды моллюсков. Это касается применения всех моллюскоцидов, представленных на рынке. Они непосредственно влияют на локальное биоразнообразие, птиц и животных, питающихся улитками.

Многие ставят пивные приманки - ёмкости, наполненные пивом, запах которого привлекает слизней, и они впоследствии тонут в этом напитке. К сожалению, народный метод не влияет на популяцию моллюсков достаточно существенно, поскольку их привлекает не только запах пива, но равно и запах другой потенциальной еды.

Тийя-Лийз Юргенсон, садовод из Эстонии, и финский разработчик дезинфицирующих средств Андрес Клейнберг изобрели некое средство от слизней. Оно основано на рапсовом масле, также туда входит соя и апельсин. Применение показало, что средство губительно не только для испанских слизней, но и других видов улиток, что сопоставляет его с гербицидами [3].

Сотрудник Ботанического сада МГУ Павел Алексашин предложил рецепт раствора от слизней для обработки растений: «Для приготовления рабочего раствора нужно чайную ложку гвоздичного масла сначала растворить в 10 мл 70\% этанола, затем довести водой раствор до 50 мл, тщательно перемешать. Полученный раствор разбавить в 1 л воды, в качестве „прилипателя“ добавить 2 капли жидкости для мытья посуды». Раствор не убивает, а отпугивает моллюсков. Однако, он действует только в течение 36 часов, после чего обработку надо производить повторно, а влияние раствора на растения ещё не рассматривалось [3].

Учёные разных стран сходятся во мнении, что единственный действительно эффективный метод борьбы с популяцией испанского слизня - это ручной сбор. Обычно собранных слизней опускают в ведро с солёной водой, где они быстро погибают от обезвоживания. Необходимо помнить, что прикасаться к этим моллюскам можно только в перчатках — во избежание заражения инфекциями, которые они переносят.

Современный научный подход к исследованию инвазивных видов предполагает выявление потенциальных возможностей их распространения или потенциальных ареалов. Благодаря наблюдениям каждый гражданин может самостоятельно оценить масштабы проблемы и возможные угрозы для различных регионов страны. В то же время ситуация в западных областях является угрожающей: слизняк там «хозяйничает» в течение десяти лет и решить проблему мгновенно никто не может. Тысячи людей тратят на сбор и уничтожение этого вредителя время, деньги и нервы. Пока люди проигрывают в этой борьбе, в том числе и экономически.

Однако нельзя опускать руки. В современном мире ученые для того, чтобы остановить экспансию различных инвазивных видов, предлагают методы, подчас весьма неожиданные. Иногда эти методы борьбы приводят к положительным результатам.

\section{Примеры эффективных нетрадиционных методов борьбы с распространением инвазивных видов}

Рассмотрим несколько удачных примеров, когда людям удалось остановить распространение инвазивных видов, гораздо более вредных, а иногда и опасных, чем испанский слизень. Среди таких видов были змеи, млекопитающие, рыбы. 


\section{Коричневая бойга}

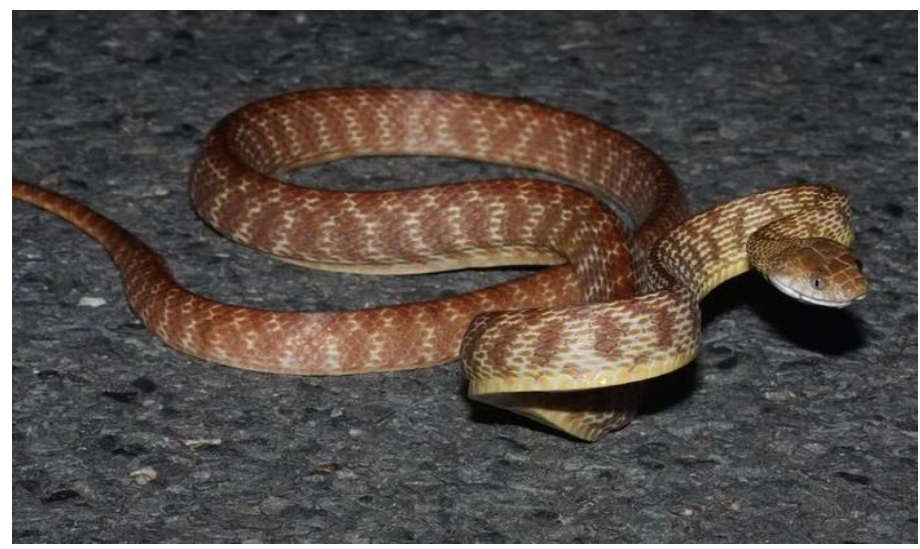

Фото. Коричневая бойга

Эти змеи появились на острове Гуам в середине прошлого века, скорее всего, их доставил вместе с грузом американский военный самолет с другого тихоокеанского острова. Среда обитания для этих пресмыкающихся оказалась настолько благоприятной, что в настоящее время их численность достигла около двух миллионов особей, которые опустошили местную экосистему. Змеями были истреблены десять из двенадцати аборигенных видов птиц, в результате чего на Гуаме развелось огромное количество пауков. Птицы также отвечали за распространение деревьев, и без них леса сильно поредели.

Бойги живут на деревьях, и попытки истребить их традиционными способами с помощью ловушек и специально обученных собак, успеха не имели. В 2013 года министерство сельского хозяйства США предложило использовать очень остроумный способ борьбы. Ученые сбрасывают с самолётов в места обитания змей мертвых мышей, накачанных парацетамолом. Грызуны медленно опускаются на вершины деревьев на маленьких парашютах. Естественно, они застревают среди веток, где раскачиваются на ветру, привлекая змей. Метод оказался весьма эффективным. Парацетамол гарантированно убивает этих змей, восьмидесяти миллиграммов достаточно, чтобы бойга впала в кому и умерла в течение 3 суток.

Мертвые мыши являются идеальной наживкой, так как они привлекают только инвазивных змей, потому что бойги - единственные змеи на Гуаме, живущие на деревьях. Учёные постоянно следят за результатами этой работы. В результате повторного сбрасывания грызунов на ранее обрабатывавшийся участок леса выяснилось, что на этот раз змеи съели на 40\% меньше мышей. Отсюда вывод, что популяция бойг уменьшилась на это значение [4].

\section{Крылатка}

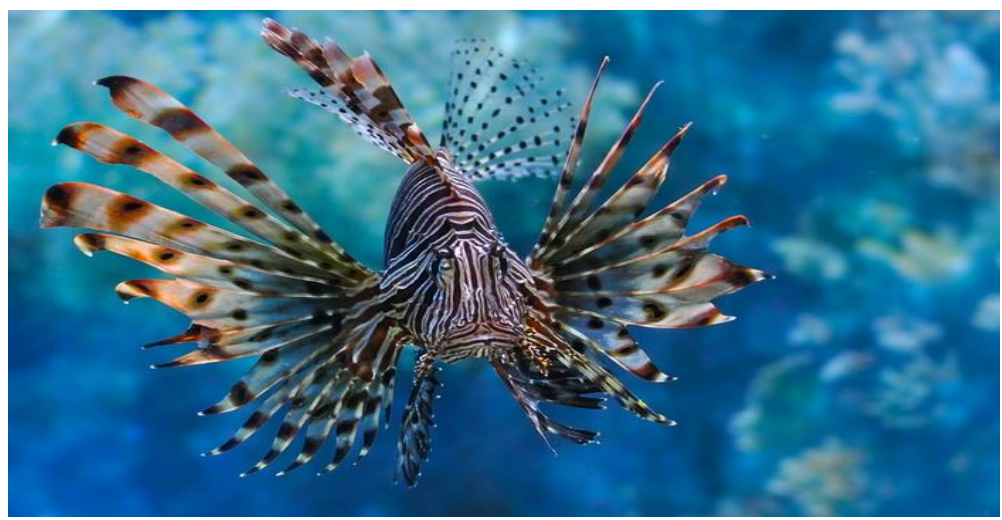

Фото. Крылатка 
Иногда инвазивными видами становятся домашние животные, например, декоративные рыбки. Именно так экстравагантная крылатка попала из Индийского или Тихого океана в Атлантический. Скорее всего, первые крылатки были выпущены в океан аквариумистами из гуманных соображений.

Однако эти существа оказались прожорливыми хищниками. Они питаются рыбой и очень ядовиты. В Атлантике на них никто не охотится, поэтому они быстро размножаются. Там, где это происходит, сокращаются местные популяции. Крылатки поедают рыб, питающихся водорослями, неконтролируемый рост которых приводит к гибели коралловых рифов. Проблема усугубляется, и выловить захватчиков традиционными методами не получится. В борьбу с ними вступила компания «iRobot», создавшая несколько лет назад робот-пылесос «Roomba».

Похожая конструкция была придумана и здесь. Это мини-роботы, которые могут работать на больших глубинах. Они подстерегают крылаток, бьют их разрядом тока, и засасывают в себя. Крылатки представляют из себя легкую добычу. Они никого не боятся, даже странного вида механизмы. Улов продаётся в рестораны. Конструкторы уверены, что им удастся высосать инвазивный вид из Атлантики [5].

\section{Американская палия}

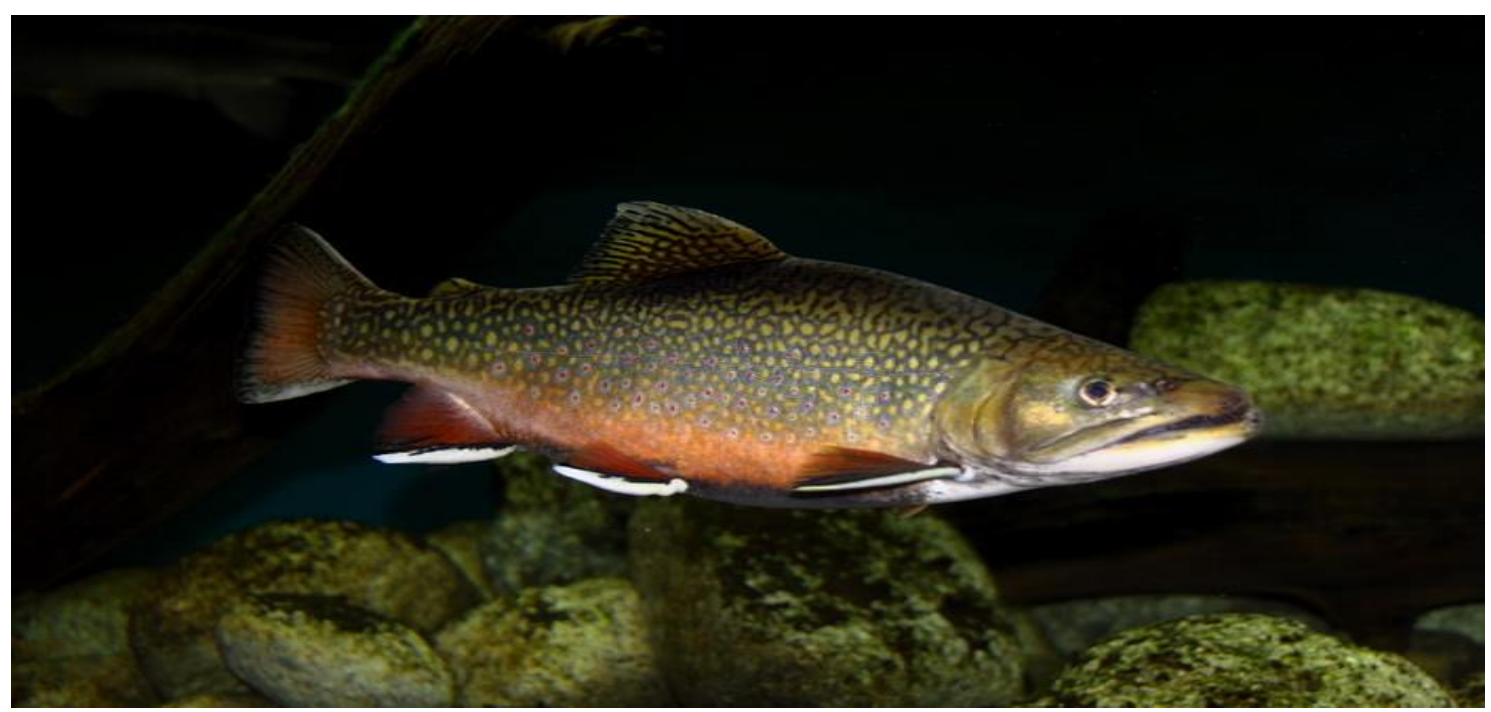

Фото. Американская палия

В верховьях реки Миссури этот вид вытесняет местные виды форели начиная с 19 века - по недосмотру рыбоводов, попытавшихся с его помощью пополнить поредевшие аборигенные популяции. В прошлом здесь пытались избавиться от пришельцев, сбрасывая в реку токсичные вещества. Понятно, что это далеко не идеальное решение - яды не различают местные и инвазивные виды, уничтожая всех подряд. Однако не так давно учёные разработали гораздо более безопасный способ удаления палии. Он также доставляет некоторые неприятности «нецелевой аудитории», однако не истребляет её как тот, что применялся прежде.

Данную технологию можно назвать «ранцевым электроловом». Люди, которым поручено очищать реку от нежелательной палии, надевают на спину рюкзаки с генераторами, забираются в воду и погружают в неё щуп, на который подаётся положительный заряд. Это естественным образом привлекает водную живность. Через какое-то время человек задействует сильный разряд, способный временно оглушить значительное количество рыбы. Она всплывает на поверхность, где её собирают сачками, после чего вручную сортируют. Инвазивная палия отправляется в рестораны, а местная форель возвращается в среду обитания. 


\section{Снежные козы}

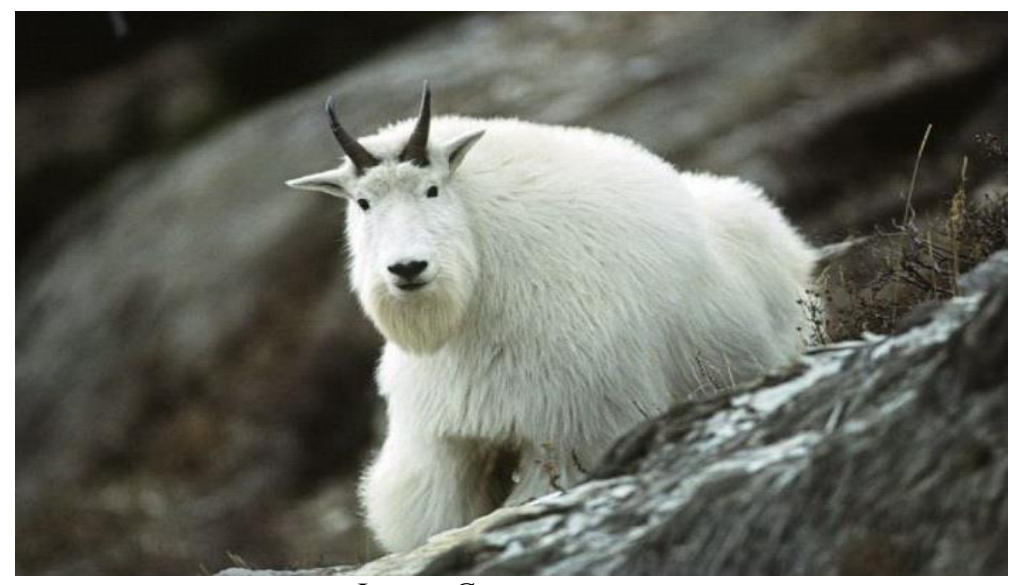

Фото. Снежные козы

В некоторых случаях в борьбе с инвазивными видами приходится искать индивидуальные методы. Так, например, обстоит дело в национальном парке «Олимпик» штата Вашингтон, где возникли серьёзные проблемы со снежными козами. Животные попали сюда в 20-х годах двадцатого века и быстро распространились в новой среде обитания. По состоянию на 2018 год около 700 коз бродили по заповеднику, вытаптывая и пожирая редкие растения. Добавляло неудобств и то, что эти парнокопытные пристрастились к человеческой моче. Оказалось, что это один из немногих источников соли в парке, и козы весьма агрессивно приставали к людям, вынуждая их поделиться ценным ресурсом.

Типичные подходы к сокращению поголовья инвазивных видов в данном случае не подходили. Рассматривалась возможность завезти в национальный парк волков, но тогда пострадали бы аборигены местной экосистемы - лоси и олени. Чтобы отвадить коз от людей, можно было бы давать им соль, но в этом случае они продолжили бы уничтожать местные растения. Поэтому было решено «выслать» этих животных на родину, в Каскадные горы. Коз сначала парализуют дротиками со снотворным, после чего завязывают им глаза, чтобы они не паниковали. Затем к делу подключается авиация - вертолёты берут на внешнюю подвеску трёх парнокопытных и доставляют их к автомобильной дороге. Здесь животные грузятся в автотранспорт и по порогам общего пользования перевозятся в Каскадные горы. Эксперты считают, что операция по передислокации поможет увеличить генетическое разнообразие коз в этом регионе, и в конечном итоге приведёт к восстановлению и процветанию местной популяции [6].

\section{Галапагосские козы}

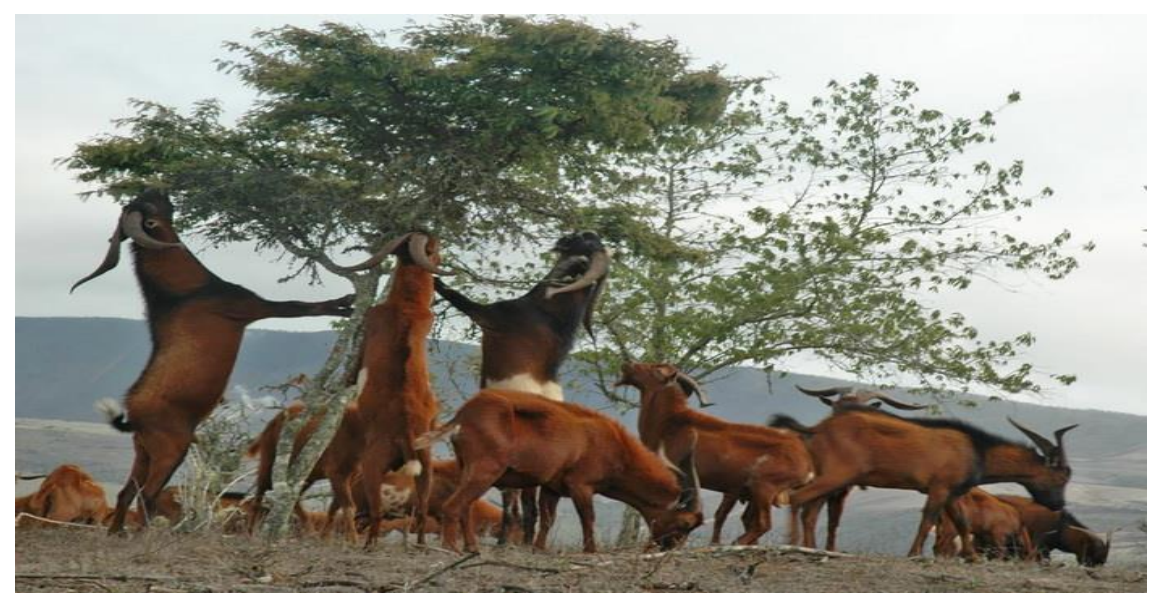

Фото. Галапагосские козы 
В борьбе с инвазивными видами животных, пожалуй, самой сложной проблемой является устранение абсолютно всех особей, до самых последних. Если дело не будет доведено до конца, может произойти довольно быстрое восстановление всей инвазивной популяции. Очень оригинальный, но очень жестокий способ решения был применен на Исабеле - одном из Галапагосских островов. Там козы уничтожили почти $80 \%$ местных видов растений, что очень отрицательно повлияло на экосистему. В 2004 году коз начали отстреливать с вертолетов. На Исабеле охотникам удалось уничтожить до 90\% этих животньх, однако использование авиации для преследования оставшихся оказалось слишком дорого. Поэтому было принято решение применить остроумную уловку.

Учёные стерилизовали 800 самок и накачали их гормональными средствами, изза чего у животных постоянно продолжалась течка. Затем на них надели ошейники с передатчиками и отпустили в дикую природу. Химически индуцированное желание продолжить род заставляло коз искать партнёров для спаривания. Охотники, наблюдающие за ними, отстреливали всех найденных животными сородичей, не имевших ошейника. Этот метод позволил исследователям достаточно быстро уничтожить всех способных к размножению коз. Стерилизованных самок трогать не стали, и они проведут остаток своей жизни, не оставив потомства [7].

Все эти примеры свидетельствуют о том, что при должной настойчивости и планомерной работе, поддерживаемой государством, победа над любыми инвазивными видами возможна.

Данные методы борьбы оказались эффективными, так как при их разработке учитывались следующие факторы: способ и сроки размножения инвазионного вида, благоприятный для размножения и жизнедеятельности климат, рацион питания, наличие естественных врагов, опасность для человека, особенности обитания и поведения. При разработке метода борьбы с Arion Vulgaris также необходимо учитывать эти параметры.

На данный момент нам известно, что в рацион Испанского слизня входит около 150 разных видов растений, овощных культур и фруктов. Наиболее любимые виды растений: зелёный салат (красные сорта более устойчивы), почти все виды капусты (брюссельская капуста, савойская капуста, белокочанная капуста, красная капуста, острая капуста, китайская капуста и др.), клубника, тыква, перец, кабачки, кольраби, огурцы, бобы, сельдерей, гречневая крупа, чечевица, редис, морковь спаржа, шпинат. Большинство трав устойчивы к поеданию слизняками, поэтому список трав, которые любят слизни небольшой: базилик, лимонная вербена, петрушка, укроп, майоран. Цветы, которые поедают слизни: ноготки, дельфиниумы (ласточкин хвост), георгины, люпин, подсолнух, одуванчики, петунии. Также они питаются грибами, экскрементами, мертвыми животными. При отсутствии пищи могут поедать друг друга [8].

Активно размножаются в период с мая по сентябрь. Как и другие моллюски, слизни - гермафродиты.

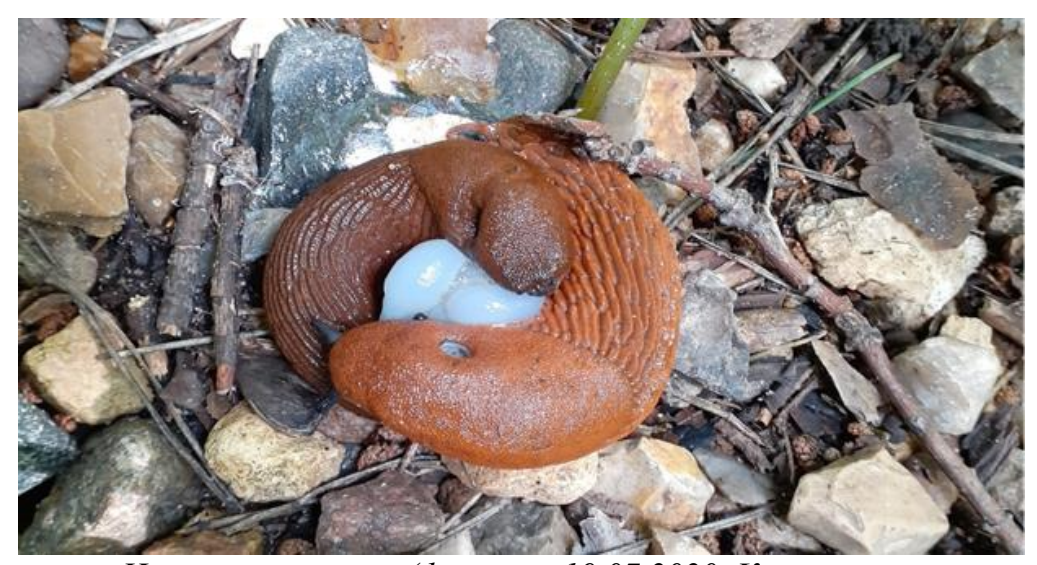

Фото. Размножение Испанского слизня (фото от 19.07.2020, Красногорский район Московской области) 
Испанский слизень умирает после откладывания яиц. Одна особь откладывает до 500 яиц за сезон. Яйца располагаются в комках по 100-200 штук. Яйца мелкие, белые, зарыты в сырых темных местах, обычно в почве, реже в кустарниках, под камнями, бревнами, досками и под другими предметами, создающими влажный микроклимат. Примерно через месяц из них выходят молоденькие моллюски. Растут и развиваются они очень быстро, достигая половой зрелости уже на второй месяц жизни, поэтому, если лето жаркое, может пройти вторая волна размножения слизней и их количество резко возрастет. Яйца способны переживать морозы до -30 градусов по Цельсию.
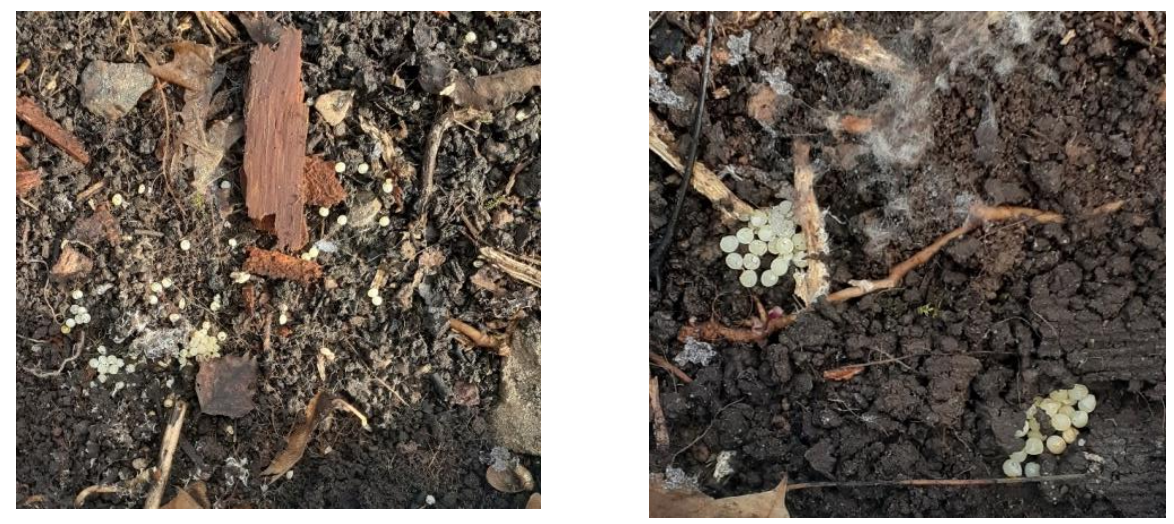

Фото. Кладки яии слизней

\section{Выводы}

Анализ текущей ситуации в местах, где испанский слизень появился относительно недавно, показывает, что сначала он, в основном, попадает с транспортом на большое расстояние не в сельскую местность, а в город - областной центр, затем через садово-огородные торговые сети распространяется на периферию по области, туда, где его еще нет.

Считают, что их размеры тела, быстрое воспроизведение, неприхотливость к продуктам питания и отсутствие врагов являются основными факторами стремительного распространения, хотя механизмы распространения испанского рыжего слизняка изучены еще не в полной мере.

Глобальные климатические изменения все больше способствуют распространению инвазивных видов наземных моллюсков. Повышение зимних температур и увеличение количества осадков в последние годы, очевидно, будет способствовать увеличению показателей их выживания. Поэтому необходимыми являются точная идентификация видов и контроль за их численностью. Пока же все держится на человеческой инициативе, данные собираются, чтобы иметь влияние на принятие решений на местном уровне и выше [9].

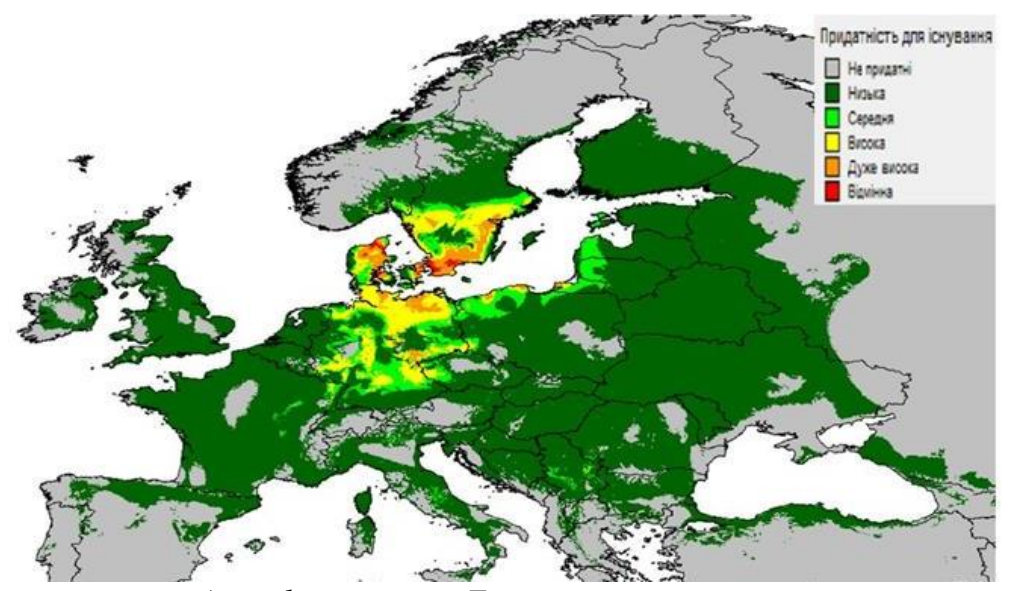

Карта потенциального ареала Arion lusitanicus в Европе при современных климатических условиях. 
В целом распространение испанского слизня на территории России требует дальнейшего изучения и выработки общей стратегии борьбы с этим вредителем.

$$
* * *
$$

1. Петросян В.Г., Дгебуадзе Ю.Ю. Самые опасные инвазионные виды России (топ - 100) [Электронный ресурс]. - Режим доступа: URL: http://researchgate.net

2. Katarzyna Turzanska. Arion slugs as nest predators of small passerine species-a review/Journal of Avian Biology [Электронный ресурc]. - Режим доступа: URL: http://avianbiology.org (2016)

3. Мария Цикура. Главный вредитель Европы. Что нужно знать об испанских слизнях? [Электронный ресурс]. - Режим доступа: URL:http://botsady.ru(2020)

4. Сергей Коленов. Змея, съевшая остров [Электронный ресурс]. - Режим доступа: URL: http://elementy.ru (2019)

5. Крылатка: экологическая проблема на Багамах [Электронный ресурс]. - Режим доступа: URL: http://pwo.su (2010)

6. Из национального парка в штате Вашингтон вывезут снежных коз, которые пристрастились к человеческим поту и моче [Электронный ресурс]. - Режим доступа: URL: http://rtvi.com (2018)

7. Дарья Лукьянова. Кто такие козы Иуды и зачем на Галапагосских островах уничтожили обычных коз [Электронный ресурс]. - Режим доступа: URL: http://travelask.ru (2020)

8. A.Boeckmann. Plants slugs love to eat [Электронный ресурс]. - Режим доступа: URL: http://slughelp.com

9. Юра Мартинович. «Остановим Рыжего»: запад Украины страдает от опасного Испанского слизняка [Электронный ресурс]. - Режим доступа: URL: http://zikua.tv

\section{Коровкина М.С., Андронова Т.А. \\ Изучение свойств киселя в зависимости от способа приготовления}

ФГБОУ ВО «Саратовский государственный медицинский университет им. В.И. Разумовского» Министерства здравоохранения РФ (Россия, Саратов)

doi: $10.18411 / \mathrm{j}-06-2021-31$

\section{Аннотация}

В настоящее время большое внимание уделяется здоровому образу жизни, ключевым составляющим которого является правильное питание. Такой продукт, как кисель, должен помогать организму поддерживать кислотность, нормализовать внутреннюю среду за счет своей структуры. В статье изучаются свойства киселя марки «Компас Здоровья», состав которого схож с киселем, приготовленным по традиционной рецептуре. В зависимости от способа приготовления образцов делаются выводы о пользе действия данного продукта на организм.

Ключевые слова: кисель марки «Компас Здоровья», состав, крахмал, органолептика, микроскопирование, набухание, клейстеризация.

\section{Abstract}

A lot of attention is currently paid to a healthy lifestyle, the key component of which is proper nutrition. A product such as kissel should help the body maintain acidity, normalize the internal environment due to its structure. The article studies the properties of "Health Compass" kissel, whose composition is similar to jelly prepared according to the traditional recipe. Depending on the method of preparing the samples, conclusions are made about the benefits of this product on the body.

Keywords: kissel (jelly) brand "Health Compass", composition, starch, organoleptic, microscopy, swelling, gelatinization.

Здоровый образ жизни- это образ жизни, основанный на принципах нравственности, рационально организованный, активный, трудовой, закаливающий, но и, в то же время защищающий от неблагоприятных воздействий окружающей среды 